\title{
present in her absence
}

\section{Carolyn Guertin}

Tantant d'obtenir une polyphonie, d'offrir une contre-perspective, Carolyn Guertin crée un supplément pour le cycle poétique "The Old and Their Knowing" ("Les vieux et leur savoir") de Robert Bringhurst. Frappée par un véritable manque dans le texte de Bringhurst, Guertin décide de le remplir. Dans sa poésie, une myriade de femmes du monde pré-socratique émerge-quelques-unes sans noms et d'autres, comme Clytemnestre, Électre, Héra et Sappho sont nommées. Mises au premier plan, finalement concrétisées en mots, leur absence laisse place à leur présence.

an excerpt from

caw

\section{caw}

\section{callings}

a counterpoint for Robert Bringhurst

Counterpoint. The ability, unique to music, to say 2 things at once comprehensively. The term derives from the expression punctus contra punctum, i.e. 'point against point' or 'note against note'. A single 'part' or 'voice' added to another is called 'a counterpoint' to that other, but the more common use of the word is that of the combination of simultaneous parts, each of significance in itself and the whole resulting in a coherent texture. In this sense Counterpoint is the same as Polyphony.

- The Oxford Dictionary of Music 


\section{Anacrusis}

I think that Robert Bringhurst's poetry is breathtaking. On reading his anthology The Calling (Toronto: McClelland, 1995), I felt compelled to respond to it as a poet in kind. As a feminist, however, there were many things in Bringhurst's politics and approach, especially in connection with pre-Socratic philosophy and Bringhurst's poetic cycle "The Old and Their Knowing," that did not ring true for me. The beauty of the preSocratics-from what we can understand in a post-Aristotilean worldwas their inability to conceive of binary oppositions. For them, it seems everything was united in a single whole: art and science, thought and emotion, poetry and philosophy, and maleness and femaleness, and a host of other binarisms. As a feminist, I felt compelled to address the absence of the female in Bringhurst's poetry-an absence that is not echoed in his critical writing.

caw caw callings, my resulting 70-page poetic response, is not to be read as a challenge to Robert Bringhurst, for I will not take him to task for what he did not intend to do. It is instead a supplement, another voice in his chorus, that addresses a resonant absence...

This excerpt entitled "presence in her absence" was exhibited in a slightly different form by Artcite Gallery in Windsor, Ontario as a part of their Telling Tales, Telling Lies show for International Women's Day in 1996. 
(present in her absence

she is present as a lack

) a void

all the mothers are conspicuous

conspicuously absent

present in absentia voiced in the silence in the gaps

in the mind in the earth

an ellipse of repressed thought

a crescent in the voicelessness

of the dreaming fluid self 
The sun may be married to the moon

but he and his words never touch her ${ }^{1}$

she enters briefly from the wings

crazed murderess

with a phobia for cleanliness

and a gift for birthing

she is present in the water as mother Amazon who is nurtured by her children:

this mother of rivers has thousands of rivers for mothers ${ }^{2}$ but she is no warrior has no partner no mate
a ghostly after- image

in a mysterious world of a forgotten shadow stillness

she is in the sky in the fluid crescent and eye

but she is

silent 
Is the sound not integral to the vision?

(Is the female not integral to the male?)

Is the vision not heard as well as seen?

It is and vision lies outside language

Vision

exists beyond the words which in their sharp loveliness house it and trace it and lead us like lovers to follow its contours time and again with our tongues ${ }^{3}$

but in these callings her tongue is fixed 
she only speaks when spoken to

her contours

are hidden behind curtains of | silence

she is underground and neurotically out of sight

but remembered with

gifts on her wedding day

so absent that she seems

jilted at the altar of song

(or she him?

too ugly in this fictional world to be allowed a mirror for the journey home into

language

she is abandoned

veiled and unknown 
Antigone is agoraphobic in a postscript

as an afterthought while even cursèd Creon is namelessly remembered

where is electrifying Electra in her murderous rage?

$$
\text { Clytemnestra? off stage }
$$

awaiting the scis sors of fate

Herakleitos is cursed with a silly daughter

even Zeus-battered Hera reduced from hurling lightning bolts to frying pans is absent

and lonely Penelope silently weaves her unending fragments

elsewhere 
she is present in dreaming

of that other philosophy

Greek voices who sing

from their fragmentary pages

of attraction and repulsion

who sing of love through the margins of

silence

listen:

I say that whatever one loves is ${ }^{4}$

Sappho sings softly

from her authoritative magnitude of fragmentary fame sweetly voicing her knowing in this feminine void

this great Presocratic Philosopher of Love is denied a heartbeat of sapphic meter from the margins 
Sappho's surly contemporary serial killer Parmenides

(who killed the bird of heart

in his thought)

he too whispered naughty secrets in the goddess' shell-shaped

ear

(he gave her credit for

devising and introducing love to the gods in his theogony ${ }^{5}$

he frolicked with the hot-tempered daughters of the sun and played mean volleyball with sun maidens on the scorching sands near Pyres' home

while star-gazing after a hasty midnight embrace it must have been he found the shape of his loves in the shapely sky

Parmenides subsequently proclaimed the earth round and voluptuous and said that all objects were suspended in a seminal fluid lighter than air

he knew

all bodies left to themselves would fall to the ground impotent ${ }^{6}$

even scorning Demokritos

who never raised his head from his work

of classifying bodies

atoms and the void alone real

vowed that the original form made

believed in the bloody feminine labour of cosmogony

a literal world-begetting

and so shaped his theories on an embryological model ${ }^{7}$ 
blazing Empedokles died in the embrace of his lover Etna he circumscribed a feminine world in his travels with his taste for colour and cooking

the 123 four elements neatly drew and quartered motherly gaia: interact under the influence of two cosmic powers Love (who is Aphrodite) and Strife (who is $?^{8}$ and engendered the gregarious microscopic universe for attractive Empedokles under Love the elements are dear to and desired by one another it is only Strife that makes them grim and hostile...9

For this philandering philosopher world formation and world destruction were only possible adrift on the sea of Love where that sacred emotion enacted cosmological creativity

and the schizo orgiastic urge

flaunted phrenic goddess in the same equal and opposite apocalyptic powers 
she is present

but silent

her face covered by care-worn hands

she is

waiting

waiting

for all of the blood shed

(not in acts of creation

but in apocalyptic destruction that is the clockwork

and machinery of an industrial age

waiting for all the blood that has been shed

to stop f 1 o $\mathrm{W}$

$\mathrm{n} \mathrm{g}$

weaving these fateful

silences

these small roots linking fingers to join in being in the fragrant earth that is heart hearth home

that is her

she is waiting

through

eternity

She is deaf, dumb and blind. But she hears

through the soles of her feet, speaks

from under her skirt, and sees

through the holes in the palms of her hands ${ }^{10}$

like Philomela this blind seer does not speak words

silence is her fluid signature 
袞

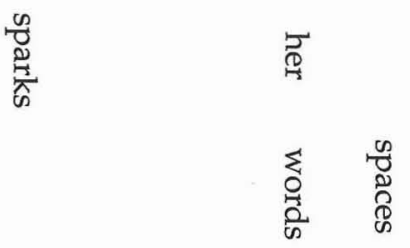

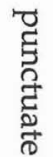


$114 \cdot$ Tessera

she is

i n art

i

c

u late

she is

sev

from the well-springs of eloquence

but not from the sources of meaning ${ }^{11}$

ered

she is

here 


\section{Notes}

1 Bringhurst Calling 216.

2 Bringhurst Calling 191.

3 Bringhurst Map 107.

4 Sappho 41.

5 Parmenides 83.

6 Lempriere 485.

7 Edwards, Volume 4, 448.

8 Edwards, Volume 2, 497.

9 Edwards, Volume 6, 444.

10 Bringhurst Calling 17.

11 Bringhurst Map 110.

\section{Works Cited}

Bringhurst, Robert. The Calling: Selected Poems 1970-1995. Toronto: McClelland, 1995.

-. Pieces of Map, Pieces of Music. Toronto: McClelland, 1986.

Edwards, Paul, ed. Encyclopedia of Philosophy. 12 Volumes. New York: Macmillan, 1967.

Lempriere, J. Lempriere's Classical Dictionary. London: Bracken, 1984.

Parmenides. Parmenides of Elea: fragments. Trans. and Ed. David Gallop. Toronto: U of Toronto P, 1984.

Sappho. Sappho: A New Translation. Trans. Mary Barnard. Berkeley: U of California P, 1958. 